\title{
Introduction: Liulichang and Qing Book Culture
}

\author{
Cynthia Brokaw \\ Brown University \\ cynthia_brokaw@brown.edu
}

By the late eighteenth century, the Liulichang 琉璃廠 district of Beijing一the site of the Imperial Glazed Tile Factory in the Ming dynasty (1368-1644) — had become home to the largest and most influential book emporium of the Qing empire (1644-1911). Until the rise of Shanghai as the center of the modern publishing industry in the early twentieth century, Liulichang overshadowed even the once-great book markets of the Jiangnan area. The district's publisherbooksellers, many of whom had gotten their start in the book trade in Jiangxi province and Jiangnan, established hundreds of shops; one count from the mid-twentieth century lists 368 bookstores and 66 publishing houses. ${ }^{1}$ By the nineteenth century, Liulichang was the major node of publishing-bookselling networks that stretched across much of China Proper and handled a complex exchange of texts from the capital to the provinces and from the provinces to the capital. ${ }^{2}$ Liulichang's influence, then, reached far beyond the important yet bounded cultural, intellectual, and artistic life of the capital.

In sum, for anyone interested in late imperial publishing and book culture, Liulichang should loom very large indeed. But studies of Liulichang in Western languages are surprisingly scarce; and the little that has been written on the subject focuses on its role in supporting elite scholarship and the sophisticated publication programs of the Qianlong era (1736-1795) or its importance as an

1 Sun Dianqi 孫殿起, Liulichang xiaozhi 琉璃廠小志 (Beijing: Beijing guji chubanshe, 200o); cited in Christopher A. Reed, 'Dukes and nobles above, scholars below: Beijing's Old Booksellers' District Liulichang, 1769-1941 — and its influence on 2oth-century Shanghai's book trade', East Asian Publishing and Society 5 (2015): 86.

2 Cynthia Brokaw, 'Empire of texts: book production, book distribution, and book culture in late imperial China', in Joseph P. McDermott and Peter Burke, eds., The book worlds of East Asia and Europe, 1450-1850 (Hong Kong: Hong Kong University Press, 2015), 214-8. 
art, antiquities, and rare book market. ${ }^{3}$ The two essays published here open a new window on Liulichang by illuminating its importance as a market for more mundane and useful objects - that is, largely commercial, relatively affordable practical aids for officials, scholars, and visitors to the capital in the form of legal texts, frequently updated directories of serving officials, and guidebooks to the city.

Ting Zhang, in 'Buying and selling law books in Qing Beijing', traces the development of the commercial publication of legal works from the late eighteenth century (when, thanks largely to official prohibitions and literary inquisitions, very few such works were produced) through the nineteenth century (which, with the loosening of government control, witnessed a boom in the production of the texts). Editions of the Qing code, compilations of substatutes and regulations, administrative rulebooks, legal and forensic handbooks, and collections of case precedents were invaluable aids to newly minted officials, scholars serving as secretaries to officials - and any literate person interested in learning about the law. In the capital, publisher-booksellers had easy access to the offices and publications (like the Peking gazette) that allowed them to keep their texts up-to-date, although they usually took advantage of the higher concentration of skilled block cutters and printers and lower costs of publication in south China to have their works manufactured in Jiangnan or Jiangxi. Their products, Zhang argues, promoted the broader dissemination of legal knowledge in the Qing.

Emily Mokros' 'Reading the guides, directories, manuals, and anthologies of Liulichang' focuses on a different set of texts: official directories (jinshen

3 Liulichang is alluded to or discussed briefly in many general works on Beijing; see, for example, Susan Naquin's Peking: temples and city life, 1400-1900 (Berkeley, CA: University of California Press, 2001). In a 2015 issue of this journal, Christopher A. Reed published a study of Liulichang, in particular its role in Beijing official and intellectual life and influence on the twentieth-century Shanghai book trade; see the reference in note 1. Shana Brown has written on the engagement of women with Liulichang in the nineteenth century; see her 'The women of Liulichang: female collectors and bibliophiles in the late Qing', in Maureen Daly Goggin and Beth Fowkes Tobin, eds, Material women, 1750-1950 (Farnham, Surrey: Ashgate Publishing Limited, 2009), 279-94. There are no thorough and comprehensive secondary studies even in Chinese. Sun Dianqi's (1894-1958) compilation of reminiscences of Liulichang, Liulichang xiaozhi (see note 1), produced in 1949, is the standard primary source for study of the book market. Three book-length secondary studies focus on the rare book and/or the antiquities market: Wang Yeqiu 王治秋, Liulichang shihua 琉璃厂史话 (Beijing: Shenghuo dushu xinzhi sanlian shudian, 1963), Sun Donghu 孙冬虎, Liulichang 琉璃厂 (Beijing: Beijing chubanshe, 2005), and, most recently, Chen Chongyuan 陳重遠, Liulichang shihua 琉璃廠史話 (Beijing: Beijing chubanshe, 2015). 
lu 縉紳錄), gazettes, guidebooks to Beijing, and forensic manuals. But she too argues for a boom in the commercial publication of these texts in the nineteenth century. In the early and mid-Qing, houses like the Rongjin tang 榮錦堂 relied on their close (often family) ties to officialdom for information and their contacts with the Jiangnan printing centers for the manufacture of their texts. The proprietor of the Rongjin tang, Li Zhen 李珍 ( $f$ l. 18th c.), took great care in researching and updating his house's legal works and saw that they were endorsed by noted scholars (for example, his relative Li Fu 李紱, 1673-1750). By the nineteenth century, however, as the number of degree holders and hopeful officials increased, the production of directories and other administrative texts was taken over by houses like the Ronglu tang 榮祿堂 / 榮錄堂, which rapidly churned out increasingly standardized editions of these and a wide range of other popular texts. It was these works, Mokros argues-and not rare Song, Yuan, and Ming volumes nor the sophisticated reference works that fueled the Siku quanshu 四庫全書 project of the previous century—that dominated book sales in late-Qing Liulichang.

These essays work beautifully together both to suggest some large conclusions about Qing publishing and book culture and to point to lines of further research. Zhang explicitly and Mokros implicitly indicate the development, by the nineteenth century at the latest, of widespread networks of book production, dissemination, and sale that could provide the foundation for an integrated book market. As both authors note, Jiangnan and Jiangxi publishers and artisans enjoyed close ties to Liulichang-indeed, many Liulichang shops were founded by men from Jiangxi or the Jiangnan area. ${ }^{4}$ But the networks extended beyond the eastern coastal regions; Zhang explains, 'Thanks to its national networks of books and merchants, Beijing publishers had convenient access to the finest editions of legal books around the empire. Texts published in the provinces made their way to Beijing; but texts on sale in Beijing could then, via those same networks, be disseminated throughout the empire. It appears, then, that Liulichang was not simply the largest book market in Qing China, but also the major nexus of an increasingly integrated network of commercial publishing operations. This integration-how tight an integration it was demands further study—in turn might have encouraged another late-Qing trend

4 Certain Qing-era publishing houses established printshops in a number of different sites throughout China Proper to create quite extensive networks of production and sale. The Shancheng tang 善成堂, to give just one example, originated in Jinxi, Jiangxi, but then branched out, over the course of the eighteenth and nineteenth centuries, to Chongqing and Chengdu, Sichuan; Dongchang 東昌 (now Liaocheng) and Jinan, Shandong; Botouzhen 泊頭鎮, Zhili; and Liulichang. Brokaw, 'Empire of texts', 216. 
that both Zhang and Mokros identify: the increasing standardization of the legal texts, official directories, and guidebooks, as publishers chose to reprint popular works rather than commission new ones. The fuller exchange of texts across China Proper, together with increased demand for texts, could have facilitated the spread of standardized legal and administrative knowledge in the late nineteenth and early twentieth centuries.

Zhang and, in particular, Mokros justly emphasize the diversity and flexibility of the publishing strategies that woodblock print technology and the different types of printing operations of late imperial China offered publishers. Mokros' directory publishers designed the woodblock 'pages' of their texts in vertical columns and placed the relatively ephemeral information in one part of the text in order to make alterations to the text, necessary whenever official appointments changed, easy. They were also able to produce 'custom' editions - cheap pocket versions up to large-scale 'official format' volumesfor customers of different economic means. Zhang notes that while some publishers took full charge of the production process, managing the block cutting, printing, and selling of their texts, others might commission a character-cutting shop (kezi dian 刻字店) to cut the blocks and print up the text on demand from customers. Seeking larger pools of skilled labor and lower production costs, the commercial publishers of Zhang's legal texts and Mokros' directories frequently looked beyond Beijing to rely on Jiangnan cutters and printers for the manufacture of their books; presumably, production was still cheaper despite the added costs of transporting the blocks or printed texts. This information confirms and elaborates the conclusions of previous scholarship on the relationships between publishers, block cutters, printers, booksellers, and consumers in the woodblock book market. ${ }^{5}$ It suggests, too, that we should continue to be alert to the ways in which woodblock and other Chinese print technologies could be adapted to suit text contents and formats; and to the variety of relationships that were formed between publishers, block

5 In his study of the production of gazetteers, Joseph Dennis shows that the texts might be sent considerable distances from their point of origin for cutting and printing; see Joseph R. Dennis, Writing, publishing, and reading local gazetteers in imperial China, 1100-1700 (Cambridge, MA: Harvard University Asia Center, 2015), 197-212. Lucille Chia notes that in the Ming, the Jianyang publishers of northern Fujian had close ties to publishing in the Jiangnan city of Nanjing; some of the publishers established shops there and others may have collaborated with Nanjing publishers: Chia, Printing for profit: the commercial publishers of Jianyang, Fujian (11th-17th Centuries) (Cambridge, MA: Harvard University Asia Center, 2002), 168, 171, 173-174, 233. See also Brokaw, 'Empire of texts', 187-194, 214-8. 
cutters, printers, binders, and booksellers—often operating over considerable distances-in the book trade.

Finally, these two essays raise important questions about the political and broader social and cultural public impact of publishing. Zhang argues that the commercial publication of legal works in the late Qing disseminated legal knowledge to the (literate) public. The implication of Mokros' essay-although she does not press this point - is that the repeated publication and sale of official directories, administrative texts, and guidebooks in the late Qing would lead to broader public knowledge of government institutions and the operations of the capital. The natural question is: what impact would this broader dissemination of knowledge have had on the public, including commoners or non-degree holders as well as scholars and officials, in the Qing? The texts that Zhang and Mokros are presenting in their essays resemble in many ways the shogunal and bureaucratic directories and guidebooks studied by Mary Elizabeth Berry in Japan in print. In this study of Tokugawa print culture, Berry identifies such texts as important sectors of a library of public information' that, by educating readers in the institutions of government and in the scenic and cultural attractions of different places in Japan, helped to forge a sense of a shared culture and shared nationhood, of 'our Japan', that provided the foundation for the development of modern nationalism in the nineteenth century. ${ }^{6}$ Could we argue that the publications analyzed in these two essays were also promoting a sense of a shared political and legal culture —or at least a shared awareness of the law and administrative procedures-in the late Qing? If so, what impact could such a culture have had on the nation-building efforts of the early twentieth century?

6 Berry, Japan in print: information and nation in the early modern period (Berkeley, CA: University of California Press, 2006), 209-52. 